\title{
Effect of land use in seasonal abundance of Eared Dove (Zenaida auriculata) in Southwestern Brazil
}

\author{
G. G. Silva and D. L. Guadagnin ${ }^{b *}$ \\ aPost-graduate Program in Animal Biodiversity, Universidade Federal de Santa Maria - UFSM, Av. Roraima, 1000, \\ CEP 97105-900, Santa Maria, RS, Brazil \\ ${ }^{b}$ Department of Ecology, Universidade Federal do Rio Grande do Sul - UFRGS, CP 5007, CEP 91501-970, \\ Porto Alegre, RS, Brazil \\ *e-mail: dlguadagnin@gmail.com
}

Received: December 16, 2015 - Accepted: August 8, 2016 - Distributed: February 28, 2018

(With 1 figure)

\begin{abstract}
Changes at the landscape scale associated with expansion in agricultural land use and changes in agricultural practices are common causes of alteration in patterns of abundance and composition of avian communities. Eared Dove (Zenaida auriculata - Des Murs, 1847) is among the most common species in the Neotropics, considered both as game and pest in some countries. Here we characterized the regional and seasonal patterns of Eared Doves abundance in Southwestern Brazil and examined the relationship between landscape features and these abundance patterns. We counted Eared Doves using the point count system along routes in summer and winter and recorded land use at two scales. We used linear regressions to model the effect of landscape matrix and land use at local scale with Doves abundance in two seasons. At the landscape scale, in winter, the abundance was greater in routes crossing landscapes dominated by plantations. In summer, it was lower in routes with large tracts of forests and mixed farming. While in winter, at the local scale, the Doves abundance was greater in routes with higher frequency of maize plantations, in summer higher abundances were observed in routes with higher frequency of sugar cane and soybean plantations. Agricultural settings, which include both sustained production of food in the form of grains as well as and large stretches of habitat suitable for reproduction, favor large population of Eared Doves.
\end{abstract}

Keywords: agricultural landscape, seasonal dove abundance, Atlantic forest fragmentation, habitat correlations, Zenaida auriculata.

\section{Efeito do uso do solo na abundância sazonal de pombas-de-bando (Zenaida auriculata) no sudoeste do Brasil}

\begin{abstract}
Resumo
Mudanças em escala de paisagem associadas à expansão das áreas destinadas à agricultura e às mudanças nas práticas agrícolas são consideradas importantes causas de alterações nos padrões de composição das comunidades de aves. A pomba-de-bando (Zenaida auriculata - Des Murs, 1847) é uma espécie comum na região Neotropical, sendo considerada tanto um recurso cinegético quanto uma peste agrícola em alguns países. Neste trabalho nós caracterizamos os padrões regionais e sazonais de distribuição populacional de pombas-de-bando em áreas agrícolas do sudoeste do Brasil e examinamos a relação entre características da paisagem e padrões de abundância de pombas. Coletamos os dados em transecções com pontos de contagem, alocados em estradas vicinais, percorridas no verão e no inverno. Utilizamos dados sobre as características da paisagem em duas escalas. Através de análises de regressões lineares modelamos o efeito da paisagem e do uso da terra na abundância de pombas nas duas estações. Na escala da paisagem, no inverno, a abundância foi maior em áreas com predomínio de agricultura. No verão a abundância foi menor em áreas com grandes extensões de florestas e agropecuária. Em relação ao uso do solo, no inverno a abundância de pombas foi maior em regiões com maior frequência de plantações de milho, enquanto no verão, a maior abundância esteve associada à maior frequência de cana-de-açúcar e soja. As paisagens agrícolas que apresentaram tanto produção de alimentos sob a forma de grãos quanto grandes extensões de habitat para a reprodução, como a cana-de-açúcar, favoreceram a ocorrência grandes populações de pombas-de-bando no sudoeste do Brasil.
\end{abstract}

Palavras-chave: paisagens agrícolas, abundância sazonal de pombas, fragmentação de Mata Atlântica, correlação de hábitat, Zenaida auriculata. 


\section{Introduction}

Agriculture expansion and changes in agricultural practices are major causes of alteration in the composition of avian communities (Chamberlain et al., 2000; Tscharntke et al., 2005; Donald et al., 2006) as a result of changes at the landscape scale. Agriculture intensification is considered one of the main factors contributing to the decline of birds in agricultural areas (Tscharntke et al., 2005; Donald et al., 2006). Loss and degradation of natural habitats, increase in fragmentation and emergence of man-made habitats threatens some species, as well as benefit other (Siriwardena et al., 1998). Some of these benefited species are able to satisfy their needs for food, shelter and reproductive habitat in the new agricultural matrix and may to dominate the assemblages (Söderström et al., 2003; Elmore et al., 2007; Dias et al., 2013) and even become overabundant and cause damage in crops or structures. Understanding the landscape settings that benefit such species and which factors contribute to population dynamics are key issues for proper management (Lutz and Jensen, 2007).

Eared Dove (Zenaida auriculata Des Murs, 1847) is one of the most common species in the Neotropics, being distributed from the Antilles to Patagonia in several Biomes, occupying many natural and man-made habitats, including urban and agricultural areas, only avoiding forested habitats (Murton et al., 1974; Sick, 1997; Souza et al., 2007). They form a superspecies with the Mourning Dove, Zenaida macroura, distributed throughout the Neartics (Goodwin, 1983; Baptista et al., 1997). Eared Doves benefited from changes in the landscape resulting from the replacement of rangelands and forested areas by agriculture, which occurred mainly after 1950 in several regions of South America (Murton et al., 1974; Ranvaud et al., 2001). Information of large population densities and damage to crops at different locations has been reported since 1970 (Londoño et al., 1972; Bucher, 1974; Murton et al., 1974; Ranvaud et al., 2001). Doves eat maize, rice and wheat grains during and soon after the harvest. They also feed on soybean cotyledons just after germination and on sorghum and sunflower during ripening. Some of the largest nesting colonies of Eared Doves in Brazil were found in sugar cane plantations (Ranvaud and Bucher 2006). Eared Dove is traditional subsistence resources in Northeast Brazil (Aguirre, 1976) where is considered threatened. Eared Dove also is considered a game and pest specie in Argentina and Uruguay (Bucher, 1974).

Although agricultural expansion and intensification are alleged causes for population increase Eared Dove, few studies explicitly analyzed the relationship between the agricultural landscape structure and the seasonal abundance of Doves. Elmore et al. (2007) found that the abundance of Mourning Doves in Mississippi increased with the percentage of land under agricultural use and decreased with the increased edge habitats. In Portugal, the abundance of Turtle Doves (Streptopelia turtur), a forest species, was related to landscape attributes associated to forest management and agricultural abandonment (Dias et al., 2013).

In the present study we examine the influence of landscape structure on the seasonal abundance of Eared Doves across Southwestern Brazil in a range of agricultural settings localized in a region that was predominantly covered by Atlantic Rain Forest. Our objectives are (1) to characterize the broad scale seasonal and regional patterns of abundance and (2) to examine if abundance of Eared Doves is positively related to landscape features. Our study focuses on a region that, while in the historical distribution area of Eared Doves, underwent major agricultural changes starting in seventies and is not included in the Biomes with historical higher abundance (Murton et al., 1974). We hypothesize that the abundance of Doves is correlated with the availability of their major food items and habitats for colonial reproduction at the landscape scale.

\section{Material and Methods}

\subsection{Study area}

The study region was located in the southernmost states in Brazil - São Paulo, Paraná, Santa Catarina and Rio Grande do Sul. We delimited the study region selecting in these states the mesoregions that were the major producers of maize, soybean and wheat in the period from 2001 to 2010 (classification established by the Brazilian Institute of Geography and Statistics - IBGE). We obtained data about the area planted with these grains in the IBGE Automatic Recovery System (IBGE, 2012). The selected mesoregions form a block in Southwestern Brazil, comprising $30 \%$ of the total area planted with maize in the country, $35 \%$ of soybean and $87 \%$ of wheat. The region studied is almost completely inserted in the Atlantic Forest Biome, including borders of the Cerrado (Tropical Grasslands) and Pampa (Temperate Grasslands). Agricultural field forms the vegetation matrix in the whole region, interspersed with patches of forestry with exotic species, native grasslands and forest remnants. Climate is humid subtropical (Köppen classification $C f a$ and $C f b$ ).

Throughout the studied region the same agricultural calendar is followed. Maize is first planted from August to December and harvested between January and July and a second cycle may begin in January-February with the harvest in June-August. Soybeans are planted from September to December and harvested between February and August; wheat and oats are winter crops, planted between March and July and harvested between July and October; sugar cane is planted between January and March and harvested from April to November with the period of harvesting being longer than that of plantation as a result of ratooning.

\subsection{Eared Doves surveys}

We essentially use the methods proposed by North American Breeding Bird Census - BBC, with adaptations to the local context and the purpose of this study. We distributed randomly 50 count routes (sampling units) among the 
mesoregions in proportion to their sizes (see Figure 1). Candidate routes were secondary and unpaved roads in rural areas.

We counted Eared Doves in transects with $20 \mathrm{~km}$ length each, traveled at average speed of $40 \mathrm{~km} / \mathrm{h}$. Each transect contained 12 equidistant point counts approximately $1.5 \mathrm{~km}$ apart. We considered records each vocal and/or visual contact with a Dove specimen. The sum of all visual and vocal records was used as an abundance index by transect. Visual counts in points along transects is the reference method for open areas (Bibby et al., 2000), such as agricultural matrices. We decided to include vocal contacts because Eared Doves nest and vocalize practically all over year in the study region (Donatelli et al., 1994; Menezes, 2001; Scherer et al., 2006; Guaraldo and Gussoni, 2015) and woodland patches could preclude the visualization of nesting birds. We took care to clearly assign the contacts, either vocal or visual to a single animal to avoid double counting. Two partners conducted the counts independently. Discrepancies in the number of Doves recorded were discussed and solved in the field and a consensus number was recorded. Counts were restricted to approximately $300 \mathrm{~m}$, a distance that we were confident that we could clearly recognize an Eared Dove with the help of binoculars. A telemeter was used to gauge the distance of birds using references in the field. The time spent in each point count was 3 minutes. Data collection was started approximately 15 minutes before sunrise and extended throughout the day, being interrupted in cases where weather conditions or human activities interfered in counts. We counted birds during the whole light ours of the day, considering that Eared Doves are active all day long. Although the method we adopted does not provide an unbiased estimate of density, it is suitable to provide a precise index of abundance for Eared Doves in the studied region for the purpose of our study (Gregory et al., 2007). We surveyed Doves in winter from July $25^{\text {th }}$ until August $10^{\text {th }}, 2012$ ) and summer from December $22^{\text {th }}$ until January $15^{\text {th }}, 2013$ ).

\subsection{Land use data}

We considered two scales of land use - landscape and local. At the landscape scale we intended to characterize the matrix of land cover in perimeters of $2 \mathrm{~km}$ around the count routes. We used the Vegetation Cover Map of Brazil made available by the Ministry of Environment (BRASIL, 2007 ) with minor updating based on visual interpretation of Quickbird Satellite images. From these maps we grouped some of the available classes to represent the major land use types of interest: Agriculture, Pastures, Grasslands, Forests, Forestry and Mixed Farming. Mixed Farming typify fine grained, variegated landscapes including

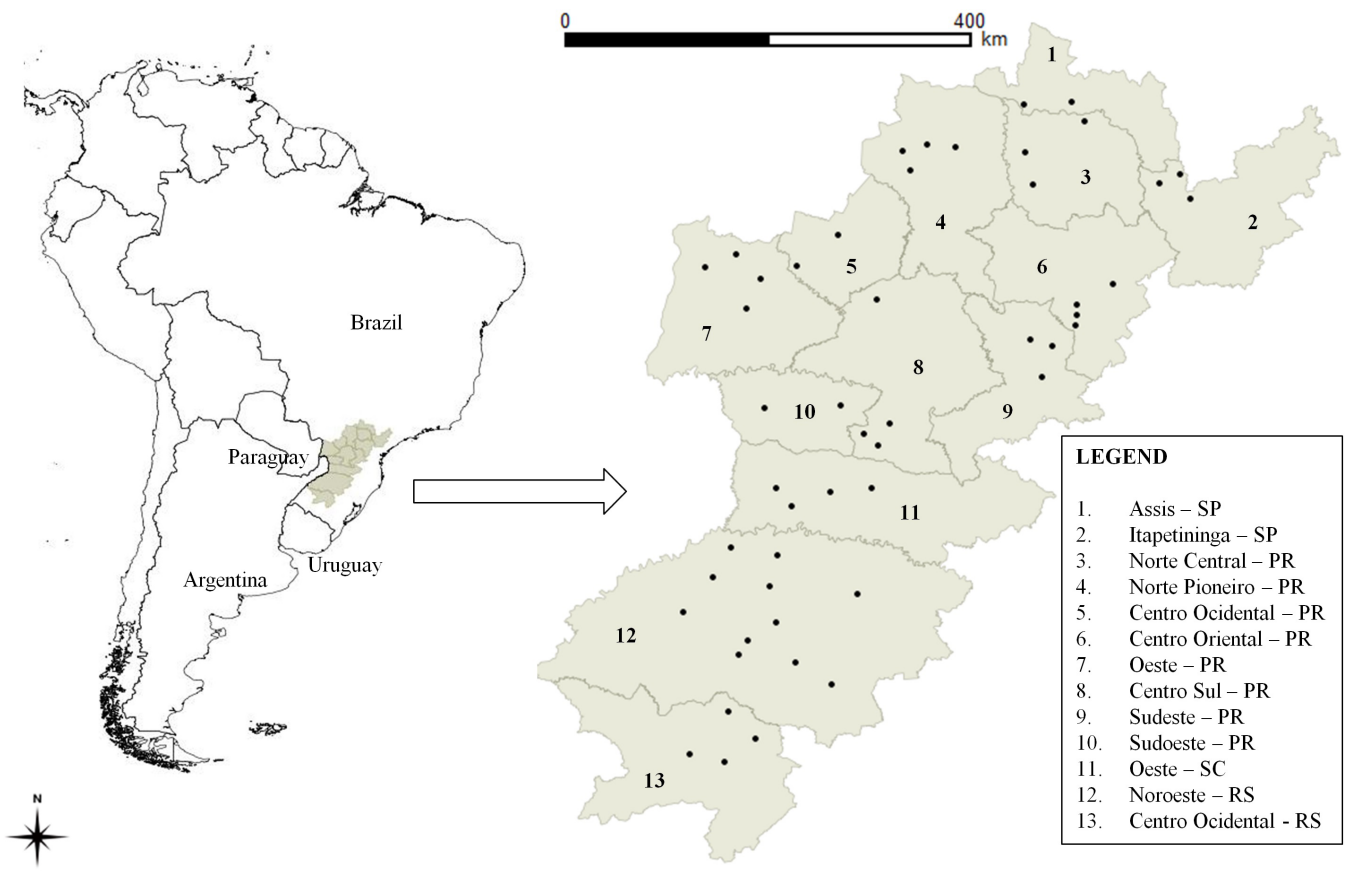

Figure 1. Study region in southwestern Brazil comprising parts of southernmost states of PR- Paraná, SC- Santa Catarina, SP - São Paulo and RS - Rio Grande do Sul. Dots represent the location of count routes of Eared Doves surveyed in the local winter (July-Aug) of 2012 and summer (Dec-Jan) of 2012-2013. 
several of the above classes, usually of small farms and farmsteads. We used the program ArcGIS 9.3 to process maps and calculate the percentage area of each land cover class along the route buffers.

At the local scale we considered the frequency of occurrence of different land uses obtained in count point, to represent a sample of landscape where routes were located. At this scale we intended to represent the local and seasonal variations in the land use. At each count point we recorded all land uses of interest present in a radius of $300 \mathrm{~m}$.

\subsection{Data analysis}

We looked for spatial independence in the data and potential gradients in the abundance of Doves calculating Moran's I values for 10 equidistant lags of $70 \mathrm{~km}$ approximately the mean distance between routes. Significance was determined by bootstrapping with 1000 runs. We used the program SAM (Rangel et al., 2010) to calculate the correlogram.

We used linear regressions to model the effect of landscape matrix and land use along the transects on the abundance of Doves in summer and winter. We analyzed separately summer and winter data, as well as landscape and local land use scales. We selected models using a stepwise backward-forward procedure based on Bayesian Information Criterion. We calculated variance inflation factors (VIF) for final models with two or more predictors to look for collinearity and checked the adjustment of the final models using ANOVA, comparing them with random models including only the intercept. To meet parametric assumptions we logged transformed Dove counts and transformed predictor variables by taking $y^{\prime \prime}=\left[y^{\prime}(N-1)+0,5\right] / N$, where $N$ is the number of data points (Smithson and Verkuilen, 2006). We visually checked the random dispersion of residuals of final models. We ran all analyses using the $l m$ function of R software 3.0.1.

\section{Results}

We recorded the presence of 18.012 of Eared Doves in the winter counts and 8.662 in the summer counts. We found Doves in all routes. The number Doves recorded per route varied between 3 and 4.095 birds in winter (Mean $=367.6 \pm 748.8$ standard deviation, $\mathrm{N}=49$ ) and between 2 and $2.095(173.24 \pm 328.3, \mathrm{~N}=50)$ in summer. One route was excluded from winter data because a nearby temporary roosting site greatly inflated the counts. The correlogram of the abundance of Eared Doves did not show autocorrelation at any distance lag.

The regional landscape and the routes were characterized by a matrix of agriculture and mixed farming (Table 1). Native forests covered up to $42.7 \%$. Maize, Soybean, Sugar cane and Pastures were the most frequent land uses (Table 2).

The linear regression models explained $6 \%$ to $20 \%$ of the variation of abundance in summer and winter as function of land use at local and landscape scales (as shown in Table 3). All final models had VIF's lower than 2,0. At the landscape scale, the abundance of Doves in winter was greater in routes crossing landscapes dominated by

Table 1. Percentage of land use classes in 50 count routes in Southwestern Brazil according to the Vegetation Cover Map of Brazil.

\begin{tabular}{lcccc}
\hline \multicolumn{1}{c}{ Land use } & Min & Max & Median & CV \\
\hline Agriculture & 0.0 & 99.2 & 32.6 & 1.0 \\
Pastures & 0.0 & 78.6 & 0.0 & 1.9 \\
Grasslands & 0.0 & 88.9 & 0.0 & 2.9 \\
Forests & 0.0 & 42.7 & 3.9 & 1.4 \\
Forestry & 0.0 & 2.3 & 0.0 & 2.6 \\
Mixed Farming & 0.0 & 98.4 & 8.9 & 1.1 \\
\hline
\end{tabular}

Table 2. Frequency of land uses in twelve counts point along routes in Southwestern Brazil recorded in winter (JulyAug/2012; 50 routes) and summer (Dec/2012-Jan/2013; 49 routes).

\begin{tabular}{|c|c|c|c|c|c|c|c|c|}
\hline \multirow{2}{*}{ Land uses } & \multicolumn{4}{|c|}{ Summer } & \multicolumn{4}{|c|}{ Winter } \\
\hline & Min & Max & Median & $\mathrm{CV}$ & Min & Max & Median & $\mathbf{C V}$ \\
\hline Maize & 0.00 & 1.00 & 0.25 & 0.8 & 0.00 & 1.00 & 0.17 & 1.1 \\
\hline Soybean & 0.00 & 1.00 & 0.92 & 0.3 & 0.00 & 0.00 & 0.00 & 0.0 \\
\hline Wheat & 0.00 & 0.00 & 0.00 & 0.0 & 0.00 & 0.92 & 0.33 & 0.8 \\
\hline Forest & 0.25 & 1.00 & 0.92 & 0.2 & 0.25 & 1.00 & 0.92 & 0.2 \\
\hline Pastures & 0.00 & 1.00 & 0.13 & 1.2 & 0.00 & 1.00 & 0.13 & 1.2 \\
\hline Eucaliptus woods & 0.00 & 0.92 & 0.42 & 0.5 & 0.00 & 0.92 & 0.42 & 0.5 \\
\hline Pinus woods & 0.00 & 0.33 & 0.00 & 1.7 & 0.00 & 0.33 & 0.00 & 1.7 \\
\hline Oats & 0.00 & 0.25 & 0.00 & 3.2 & 0.00 & 0.92 & 0.42 & 0.7 \\
\hline Sorghum & 0.00 & 0.00 & 0.00 & 0.0 & 0.00 & 0.17 & 0.00 & 5.2 \\
\hline Sugar cane & 0.00 & 0.83 & 0.00 & 2.5 & 0.00 & 0.66 & 0.00 & 2.2 \\
\hline Sunflower & 0.00 & 0.08 & 0.00 & 7.1 & 0.00 & 0.08 & 0.00 & 7.1 \\
\hline
\end{tabular}


Table 3. Models relating Eared Dove abundance in Southwestern Brazil with land uses at two different spatial scales.

\begin{tabular}{lcc}
\hline \multicolumn{1}{c}{ Landscape scale } & Estimate $\pm \mathbf{S E}$ & $\mathbf{p}$ \\
\hline Winter $\left(R^{2}=0.21\right)$ & & $<0.001$ \\
Intercept & $1.87 \pm 0.35$ & $<0.001$ \\
$\%$ cover of agriculture & $1.75 \pm 0.46$ & 0.016 \\
$\%$ cover of mixed farming & $1.14 \pm 0.45$ & $<0.001$ \\
Summer $\left(R^{2}=0.13\right)$ & & 0.031 \\
Intercept & $3.16 \pm 0.13$ & 0.021 \\
\% cover of forests & $-1.70 \pm 0.76$ & $\mathrm{p}$ \\
\% cover of mixed farming & $-0.50 \pm 0.21$ & $<0.001$ \\
Winter $\left(R^{2}=0.07\right)$ & Estimate $\pm \mathrm{SE}$ & 0.036 \\
Intercept & & $<0.001$ \\
Frequency of maize plantations & $2.74 \pm 0.16$ & 0.002 \\
Summer $\left(R^{2}=0.19\right)$ & $0.74 \pm 0.34$ & 0.056 \\
Intercept & & $2.24 \pm 0.26$ \\
Frequency of sugarcane plantations & $1.21 \pm 0.43$ & \\
Frequency of soybean plantations & $0.60 \pm 0.31$ & \\
\hline
\end{tabular}

plantations and in summer was lower in routes with large stretches of forests and mixed farming. At the local scale the abundance of Doves in winter was greater in routes with higher frequency of maize plantations and in summer in routes with higher frequency of sugar cane and soybean plantations.

\section{Discussion}

Our results suggest that the abundance of Eared Doves across a large region is influenced by land use at both local and landscape scales. The highest numbers of Eared Doves, both in winter and summer counts, were found in transformed agricultural landscapes dedicated to the production of grain crops. Eared Doves tended to concentrate in areas with higher frequency of maize and soybean plantations. Maize was the most abundant food item ( $46 \%$ of dry weight) of Eared Doves in a study in the same region (Ranvaud et al., 2001). Sugar cane plantations, known as potential sites for reproductive colonies (Ranvaud and Bucher, 2006), also favored higher abundances in summer. The availability of grasslands, natural habitats for Eared Doves, did not influence abundance, possibly because they do not provide the same amount of food as the agricultural areas. Native forests, as expected for a species adapted do open habitats, was inversely related with abundance of Doves. The availability of water, suggested by Bucher and Ranvaud (2006) as a key factor for population outbreaks in seasonal and semi-desert regions of South America, was not a relevant factor in our study probably because water is not a limiting factor in subtropical, humid climates. The opposite effect of mixed farming matrices in summer and winter is difficult to explain with available information. One possibility is that mixed farming areas may favor the establishment of temporary roosting sites in winter, but not the reproductive colonies in summer. Eared Doves are known to concentrate in colonies of up to several million birds in sugar canes plantations in the region (Menezes, 2001; Ranvaud et al., 2001).

Several previous studies pointed out the adaptation of Eared Doves to agricultural areas, but this is the first study to demonstrate that its abundance is influenced by the land use at multiple spatial scales. Murton et al. (1974) and Bucher and Ranvaud (2006) suggested that population outbreaks of Eared Doves in South America were driven by agricultural expansion over grasslands or previously forested areas, which increased the availability of water and grains sustainably over the whole year and provided adequate areas for colonial breeding. We showed that not only population outbreaks, but also minor variations in abundance in space and time, are related to the agricultural use of the land.

The data obtained by methods used in surveys of bird census as the North American Breeding Bird have biases that should be considered in data analysis, especially when the focus is on population changes over years (Ralph et al., 1995; Link and Sauer, 1998; Sauer et al., 2003). We consider that these biases were systematic and the method adopted is reliable for a study designed for a single, common and easily identifiable species in an agricultural landscape. Our models, including only variables describing the spatial context of land use, were able to explain part of the variations in the abundance of Eared Doves across a large region. Several other factors not investigated here might help explain the abundance of Doves in specific places, as the abundance of spilled grains along roads and left over in the fields and the adoption of non-tillage practices. Bucher (1974) and Bucher and Ranvaud (2006) suggested that spilled grains are the major source of food for Doves, even though they eat ripening crops of some cultures, specially sorghum and sunflower. Eared Doves tend to form communal roosts and reproductive colonies and fly straight from those to feeding areas, so the location of roosts and colonies and direction of flights may also 
influence counts along routes. Eared Doves can fly up to one hundred kilometers daily between roosting and feeding areas (Bucher and Bocco, 2009). Besides spilled grains, Eared Doves eat sprouts and grains during short, specific periods during the cultivation cycle (Londoño et al., 1972; Bucher, 1974; Ranvaud et at., 2001), so the availability of these crops at these specific stages could also be relevant. Moreover, it is still not known which the limiting factor is at each season of the year. A proper, not yet know proportion of feeding and reproductive habitats was suggested to explain population outbreaks by Bucher and Ranvaud (2006). Recorded episodes of outbreaks and conflicts with agriculture in the same region we studied happened in areas with a mosaic of different crops including rice, maize, soybean and sugar cane (Bucher and Ranvaud, 2006), which probably offered abundant shelter and food for longer periods of the year. Moreover, nomadism, associated with the availability of seeds of Croton spp. and other species and unevenly distributed rain over seasons and years was suggested as a major driver of population fluctuations over large areas in the past (Murton et al., 1974; Souza et al., 2007). If true, migratory patterns over larger regions could also be important.

Eared Doves are both a natural renewable subsistence resource and a pest in different parts of its distribution. This species showed several episodes of population outbreaks and conflicts with agriculture. The management of this species in agricultural areas of Southwestern Brazil, for different purposes, as renewable resource, as game or for damage control would benefit from a deeper understanding of the relationship between abundance and land use. We showed that agricultural settings that include both sustained production of food in the form of grains and sprouts, and large stretches of habitat for reproduction favor large populations. This information is also important for conservation of the threatened Eared Dove populations of the Caatinga biome where the monoculture of grains has increased in the last decades. The increase in availability and in permanence of food in the landscape can in future influence the pattern of abundance and migration of populations in northeastern Brazil, as occurred in Pampa biome in the past. In the study region, the presence of sugar cane plantations if associated with areas of maize production in winter and soybean plantations in summer, form the most favorable landscape for Eared Doves. Future studies should investigate the influence on population levels of a sustained offer of waste grains and of sprouts at the landscape scale, related with the timing of cultivation of different crops, as well as the importance of the combined matrix of mixed farming, sugar cane, and grain plantations.

\section{Acknowledgements}

We thank to R. G. de Moura for his help with data analysis, F.C. e Silva for assisting with the field expeditions and Dove surveys and Dr. R. Ranvaud for reviewing comments and contributions to this manuscript. The study was partially supported by a grant from the CBC Company.

\section{References}

AGUIRRE, A.C., 1976. Distribuição, costumes e extermínio da "avoante" do nordeste, Zenaida auriculata noronha Chubb. Rio de Janeiro: Academia Brasileira de Ciências. 35 p.

BAPTISTA, L.F., TRAIL, P.W. and HORBLIT, H.M., 1997. Family Columbidae (pigeons and Doves). In: J. Del Hoyo, A. Elliot and J. Sargatal, eds. Handbook of the Birds of the World. Barcelona: Lynx Edicions, Sandgrouse to cuckoos, vol. 4, pp. 60-243.

BIBBY, C.J., BURGESS, N.D. and HILL, D.A., 2000. Bird census techniques. 2nd ed. Londres: Academic Press. 256 p.

BRASIL. Ministério do Meio Ambiente - MMA, 2007 [viewed in 27 June 2013]. Mapa de Cobertura Vegetal do Brasil [online]. Available from http://www.mma.gov.br/component/k2/ item/7626? Itemid $=926$

BUCHER, E.H. and BOCCO, P.J., 2009. Reassessing the importance of granivorous pigeons as massive, long-distance seed dispersers. Ecology, vol. 90, no. 8, pp. 2321-2327. PMid:19739393. http:// dx.doi.org/10.1890/08-2077.1.

BUCHER, E.H. and RANVAUD, R., 2006. Eared Dove outbreaks in South America: patterns and characteristics. Acta Zoologica Sinica, vol. 52, pp. 564-567.

BUCHER, E.H., 1974. Bases ecológicas para el control de la paloma torcaza (Zenaida auriculata). Córdoba: Centre for Applied Zoology, National Córdoba University. $14 \mathrm{p}$

CHAMBERlaIN, D.E., FUlleR, R.J., BUNCE, R.G., DUCKWORTH, J.C. and SCHURBB, M., 2000. Changes in the abundance of farmland birds in relation to the timing of agricultural intensification in England and Wales. Journal of Applied Ecology, vol. 37, no. 5, pp. 771-788. http://dx.doi. org/10.1046/j.1365-2664.2000.00548.x.

DIAS, S., MOREIRA, F., BEJA, P., CARVALHO, M., GORDINHO, L., REINO, L., OLIVEIRA, V. and REGO, F., 2013. Landscape effects on large scale abundance patterns of Turtle Doves Streptopelia turtur in Portugal. European Journal of Wildlife Research, vol. 59, no. 4, pp. 531-541. http://dx.doi.org/10.1007/ s10344-013-0702-2.

DONALD, P.F., SANDERSON, F.J., BURFIELD, I.J. and VAN BOMMEL, F.P., 2006. Further evidence of continent-wide impacts of agricultural intensification on European farmland birds, 19902000. Agriculture, Ecosystems \& Environment, vol. 116, no. 3, pp. 189-196. http://doi.org/10.1016/j.agee.2006.02.007. >

DONATELLI, R.J., GAZZETTA, C.A., SILVA, M.C., SERRA, M.A.S., PEZZUTO, N.L., ANDRELA, S. and LEONEL, W., 1994. Aspectos da biologia reprodutiva de Zenaida auriculata (De Murs, 1847) (Aves: Columbiformes). Salusvita, vol. 13, no. 1, pp. 71-85.

ELMORE, R.D., VILELLA, F.J. and GERARD, P.D., 2007. Landscape correlates along mourning dove call-count routes in Mississippi. The Journal of Wildlife Management, vol. 71, no. 2, pp. 422-427. http://dx.doi.org/10.2193/2004-267.

GOODWIN, D., 1983. Pigeons and Doves of the world. 3rd ed. New York: Cornell University Press. 446 p.

GREGORY, R.D., GIBBONS, D. W. and DONALD, P. F., 2007. Bird census and survey techniques. In: W.J. SUTHERLAND, I. NEWTON and R.E. GREEN. Bird ecology and conservation: $a$ handbook of techniques. Oxford: Oxford University Press, pp. 17-56. 
GUARALDO, A. C. and GUSSONI, C.O.A., 2015. Data on nest and eggs of the Eared Dove (Zenaida auriculata)(Des Murs, 1847) in an urban area in São Paulo, Brazil. Ornithologia, vol. 7 , no. 2 , pp. 39-41.

INSTITUTO BRASILEIRO DE GEOGRAFIA E ESTATÍSTICA - IBGE, Sistema IBGE de Recuperação Automática - Sidra [online], 2012 [viewed 27 May 2012]. Available from: https:// sidra.ibge.gov.br/

LINK, W.A. and SAUER, J.R., 1998. Estimating population change from count data: application to the North American Breeding Bird Survey. Ecological Applications, vol. 8, no. 2, pp. 258-268. http://dx.doi.org/10.1890/1051-0761(1998)008[0258:EP CFCD]2.0.CO;2.

LONDOÑO, J.F., ELÍAS, D.J., VALENCIA, D. and WORONECKI, P.P., 1972. Informe preliminar sobre la incidencia de Torcaza naguiblanca (Zenaida auriculata) y su relación con problemas de daño a algunos cultivos en el Valle del Cauca, Colombia. Bogota: Colombian Agricultural Institute.

LUTZ, M. and JENSEN, F.P., 2007. Management Plan for Turtle Dove (Streptopelia turtur) 2007-2009. Luxemburgo: Office for Official Publications of the European Communities. 42 p. Technical Report - 007-2007.

MENEZES, L.N., 2001. Organização temporal da reprodução da pomba-amargosa (Zenaida auriculata) (Aves - Columbidae) no Médio Paranapanema. São Paulo: Universidade de São Paulo, 95 p. Dissertação de Mestrado em Fisiologia Animal.

MURTON, R.K., BUCHER, E.H., NORES, M., GOMEZ, E. and REARTES, J., 1974. The Ecology of the Eared Dove (Zenaida auriculata) in Argentina. The Condor, vol. 76, no. 1, pp. 80-88. http://dx.doi.org/10.2307/1365986.

RALPH, C.J., SAUER, J.R. and DROEGE, S., 1995. Monitoring bird populations by point counts. Washington: USDA Forest Service. 192 p. Technical Report. http://dx.doi.org/10.2737/ PSW-GTR-149.

RANGEL, T.F., DINIZ-FILHO, J.A.F. and BINI, L.M., 2010. SAM: a comprehensive application for Spatial Analysis in Macroecology. Ecography, vol. 33, no. 1, pp. 46-50. http://dx.doi. org/10.1111/j.1600-0587.2009.06299.x.

RANVAUD, R. and BUCHER, E.H., 2006. Eared Dove population explosions in South America: the case of southern Brazil - sugar cane and agricultural crops in tropical rainforest. Acta Zoologica Sinica, vol. 52, pp. 568-569.
RANVAUD, R., FREITAS, K.C., BUCHER, E.H., DIAS, H.S., AVANZO, V.C. and ALBERTS, C.C., 2001. Diet of Eared Doves (Zenaida auriculata, Aves, Columbidae) in a sugar-cane colony in South-eastern Brazil. Brazilian Journal of Biology $=$ Revista Brasileira de Biologia, vol. 61, no. 4, pp. 651-660. PMid:12071322. http://dx.doi.org/10.1590/S1519-69842001000400015.

SAUER, J.R., FALLON, J.E. and JOHNSON, R., 2003. Use of North American Breeding Bird Survey Data to estimate population change for bird conservation regions. The Journal of Wildlife Management, vol. 67, no. 2, pp. 372-389. http://dx.doi. org/10.2307/3802778.

SCHERER, A., SCHERER, J. and PETRY, M. V., 2006. Reprodução e análise da composição de ninhos de Zenaida auriculata (Des Murs, 1847) (Aves; Columbiformes, Columbidae) em uma unidade petroquímica no Rio Grande do Sul, Brasil. Comunicações do Museu de Ciências da PUCRS, vol. 19, no. 1, pp. 29-38.

SICK, H., 1997. Ornitologia brasileira. Rio de Janeiro: Nova Fronteira. $912 \mathrm{p}$.

SIRIWARDENA, G.M., BAILLIE, S.R., BUCKLAND, S.T., FEWSTER, R.R., MARCHANT, J.H. and WILSON, J.D., 1998. Trends in the abundance of farmland birds: a quantitative comparison of smoothed Common Birds Census indices. Journal of Applied Ecology, vol. 35, no. 1, pp. 24-43. http://dx.doi. org/10.1046/j.1365-2664.1998.00275.x.

SMITHSON, M. and VERKUILEN, J., 2006. A better lemon squeezer? Maximum-likelihood regression with beta-distributed dependent variables. Psychological Methods, vol. 11, no. 1, pp. 5471. PMid:16594767. http://dx.doi.org/10.1037/1082-989X.11.1.54.

SÖDERSTRÖM, B., KIEMA, S. and REID, R.S., 2003. Intensified agricultural land-use and bird conservation in Burkina Faso. Agriculture, Ecosystems \& Environment, vol. 99, no. 1-3, pp. 113-124. http://dx.doi.org/10.1016/S0167-8809(03)00144-0.

SOUZA, E. A., TELINO-JÚNIOR, W. R., NASCIMENTO, J.L.X., LYRA-NEVES, R. M., AZEVEDO-JÚNIOR, S. M., FILHO, C. L. and SCHULZ NETO, A., 2007. Estimativas populacionais de avoantes Zenaida auriculata (Aves Columbidae, Des Murs, 1847) em colônias reprodutivas no Nordeste do Brasil. Ornithologia, vol. 2 , no. 1 , pp. 28-33.

TSCHARNTKE, T., KLEIN, A.M., KRUESS, A., STEFFANDEWENTER, I. and THIES, C., 2005. Landscape perspectives on agricultural intensification and biodiversity - ecosystem service management. Ecology Letters, vol. 8, no. 8, pp. 857-874. http:// dx.doi.org/10.1111/j.1461-0248.2005.00782.x. 